\title{
Influence of ruminally dispensed monensin and forage maturity on intake and digestion
}

\author{
E.L. FREDRICKSON, M.L. GALYEAN, M.E. BRANINE, B. SOWELL, AND J.D. \\ WALLACE
}

\begin{abstract}
Authors are former graduate assistant, professor, former research associate, former graduate assistant, and professor, Dept. of Animal and Range Sci., New Mexico State University, Las Cruces, 88003-0003. Fredrickson is currently research scientist, USDA/ARS, Jornada Experimental Range, Las Cruces, N.M. 88003-0003. Galyean is superintendent, Clayton Livestack Research Center, Clayton, N.M. 88415 . Branine is Beef Cattle-Clinical Development Project Leader, SmithKline Beecham, West Chester, Penn. Sowell is assistant professor, Montana State University, Bozeman.
\end{abstract}

\begin{abstract}
Eight ruminally cannulated crossbred steers (average weight 336 kg) grazing native blue grama (Bouteloua gracilis [H.B.K.]) rangeland were used in a repeated measures design to evaluate effects of monensin ruminal delivery devices (MRDD) and forage phenology on ruminal digestion. Three periods were assessed: midAugust (Aug.), early October (Oct.), and mid-November (Nov.). One MRDD was placed in the reticulum of 4 steers via the ruminal cannula 21 days before each period. Intake was estimated using total fecal collections. Diet samples were collected using 3 esophageally fistulated steers. Ruminal fill was measured by ruminal evacuation; rate and extent of in situ ruminal neutral detergent fiber disappearance were estimated before ruminal evacuations. Ruminal passage rates, retention time, and apparent total tract organic matter digestibility were estimated using indigestible neutral detergent fiber. In vitro organic matter disappearance of esophageal masticate did not differ $(P>.05)$ in Aug. and Oct. (average of 53.7\%), but declined $(P<.05)$ in Nov. $(48.7 \%)$, whereas organic matter digestibility was greater $(P<.10)$ in Aug. $(62.3 \%)$ than in either Oct. (55.2\%) or Nov. (53.9\%). Release of monensin from the bolus ( $68 \mathrm{mg} \mathrm{day}^{-1}$ ) was less than expected (100 $\mathrm{mg} \mathrm{day}^{-1}$ ). Intake, organic matter digestibility, ruminal passage rates, retention time, pH, and ammonia were not affected $(P>.10)$ by $M R D D$. In situ neutral detergent fiber disappearance at 96 hours was decreased $(P<.10)$ by MRDD (68 vs 65\% for control and MRDD, respectively). As the grazing season progressed, intake declined $(P<.10)$, whereas ruminal fill and retention time increased $(P<.05)$, and passage rate of indigestible neutral detergent fiber decreased $(P<.05)$. At 48 hours in situ neutral detergent fiber was greatest $(P<.05)$ in Aug. and least $(P<.05)$ in Nov.
\end{abstract}

\section{Key Words: beef cattle, digestion, rangeland, forage quality}

Supplementing grazing beef cattle with the polyether ionophore, monensin, using grain or protein supplements as carriers increases daily gain (Oliver 1975, Potter et al. 1976, Horn et al. 1981, Goodrich et al. 1984, Wagner et al. 1984). Nonetheless, labor and carrier cost associated with daily monensin supplementation can substantially reduce its cost effectiveness. To decrease supplementation cost, salt-limiting (Muller et al. 1986) and ruminally dispensed (Parrot et al. 1986) methods of administering monensin have been developed. Regulation of monensin intake with salt does not eliminate labor cost or adequately control monensin dosage (Parrott et al. 1990). Monensin ruminal delivery devices (MRDD) are designed

\footnotetext{
The authors gratefully acknowledge the technical assistance of R. Betty and R.E. Estell.

Contribution of the New Mexico Agricultural Experiment Station, Las Cruces. Manuscript accepted 11 Nov. 1992.
}

to deliver $100 \mathrm{mg} \mathrm{day}^{-1}$ of monensin in the rumen for a period of 150 days. This delivery method substantially decreases labor cost and eliminates carrier cost. Reported increases with MRDD in daily gain by steers and heifers range from 2.3 to $13.1 \%$ over a broad range of pasture types (Parrott et al. 1990). Mechanisms by which monensin increases daily gain include increased molar proportion of ruminal propionate (Dinius et al. 1976, Dinius et al. 1978), decreased methanogenesis (Thornton and Owens 1981, Wedegaertner and Johnson 1983), and possible changes in animal metabolism (Galyean and Owens 1988). In addition, Ellis et al. (1984) suggested when monensin is supplemented to forage diets ( 45 to $65 \%$ organic matter digestibility) with a grain carrier, forage intake and utilization are increased. This increase is believed to result from an increase in ruminal fill of undigested dry matter and a decrease in ruminal turnover of forage residues.

The objective of our study was to determine the effects of MRDD on intake and ruminal digestion of forages. Use of this bolus allows monensin to be examined in a grazing context without possible confounding effects of grain-based carriers. To determine effects of forage quality on ruminal digestion of forages and to address the concerns expressed by Sprott et al. (1988) that efficacy of monensin is likely to vary with forage quality, the experiments were conducted at 3 different times during the grazing season.

\section{Materials and Methods}

The study was conducted at the Clayton Livestock Research Center in northeastern New Mexico during summer and fall, 1987. Eight ruminally cannulated crossbred [Longhorn $\times$ (Hereford $X$ Angus)] steers (initial weight $336 \mathrm{~kg}$ ) grazed a 12-ha native blue grama (Bouteloua gracilis [H.B.K.]) pasture during three, 14-day collection periods. Water and salt blocks containing trace minerals (All-Min Mineral Block, Worley Mills, Clovis, N.M.) were available at all times. Sample collection periods were conducted during mid-August (Aug.), early October (Oct.), and mid-November (Nov.). Four steers were assigned randomly to receive 1 bolus (provided by Lilly Research Laboratories, Greenfield, Ind. 46104) during each sampling period. The bolus was placed in the reticulum via the ruminal cannula 21 days before each collection period; this procedure was designed to ensure that each bolus would be at the same stage of monensin delivery during each period. Monensin ruminal delivery devices were removed from each steer at the completion of each sample collection period. Between periods, all steers grazed a similar adjacent pasture to prevent forage availability from becoming a limiting factor in the study pasture. All steers were weighed on day 1 and 14 of each period.

On days 1 and 2 of each collection period, 3 esophageally fistu- 
lated steers ( 2 steers during Nov.) grazing in common with ruminally cannulated steers, were used to obtain representative diet samples. Morning and afternoon esophageal extrusa collections (approximately 30 to 40 min per collection) were obtained without prior fasting. Esophageal masticate was composited by steer within period, freeze dried, and analyzed for neutral detergent fiber, acid detergent fiber, acid detergent lignin, acid detergent insoluble nitrogen (Goering and Van Soest 1970), and in vitro organic matter disappearance (Tilley and Terry 1963). Ruminal fluid inoculum for in vitro organic matter disappearance estimations was obtained from steers fed blue grama hay. In vitro organic matter disappearance of forage from all 3 collection periods was measured in 1 in vitro run conducted after completing the pasture phase of the experiment. Nitrogen, dry matter, and ash were constituents analyzed by standard methods (AOAC 1984). Available N (nitrogen) was calculated by subtracting acid detergent insoluble $\mathrm{N}$ from total Kjeldahl N. During each period, an aliquot of the composited esophageal masticate was air dried for 72 hours at $45^{\circ} \mathrm{C}$, then ground to a $2-\mathrm{mm}$ screen to provide substrate for estimates of in situ neutral detergent fiber disappearance.

All steers were equipped with total fecal collection bags on days 3 through 6 , and total fecal output was measured. Before initiating the study, all steers were sufficiently tamed and fitted with fecal bags to lessen possible stress caused by total fecal collection techniques; this procedure should have reduced negative effects of fecal collections on intake and increased the accuracy of fecal output measurements. Fecal bags were emptied twice daily (0600 and 1800 hours) to decrease animal stress and minimize fecal loss from the bags. Feces were weighed and mixed thoroughly, subsampled, composited within steer across days, and freeze dried for analysis of dry matter and ash (AOAC 1984). Organic matter intake was estimated by dividing fecal organic matter output by in vitro organic matter indigestibility or by marker-based estimates of organic matter digestibility (described later).

In situ neutral detergent fiber disappearance was estimated on days 8 to 11 . Approximately $3 \mathrm{~g}$ of esophageal masticate was placed in 9-cm $\times 16-\mathrm{cm}$ nylon bags (mean pore size of $28 \mu \mathrm{m} \times 40$ $\mu \mathrm{m})$. Duplicate bags plus a blank were placed in the rumen of each animal and removed after incubation times of $0,3,6,9,12,24,48$, 72 , and 96 hours. Upon removal, bags were rinsed in tap water until the water passing through the bag was clear. Bags were dried at $50^{\circ}$ $\mathrm{C}$ for 48 hours, followed by $100^{\circ} \mathrm{C}$ for 1 hour. Residue remaining in the bags was weighed and neutral detergent fiber content determined (Goering and Van Soest 1970). Values of neutral detergent fiber disappearance were fitted to the model described by Mertens and Loften (1980) to calculate rates of neutral detergent fiber disappearance.

At hour 0800 on day 12 , the rumen of each steer was evacuated manually, and digesta was weighed. Digesta was mixed thoroughly, and a subsample freeze dried to determine dry matter, organic matter, and neutral detergent fiber contents. A subsample of ruminal digesta was strained through 4 layers of cheesecloth, and $100 \mathrm{ml}$ of ruminal fluid were collected. Ruminal $\mathrm{pH}$ was measured (combination electrode), afterwhich the sample was acidified with $1 \mathrm{ml}$ of $7.2 \mathrm{~N}$ sulfuric acid and frozen at $-20^{\circ} \mathrm{C}$. Later, samples were thawed and centrifuged at $10,000 \times$ gravity for $12 \mathrm{~min}$. Supernatant fluid was used to measure ruminal ammonia colorimetrically using the phenol-hypochlorite assay of Broderick and Kang (1980). Ruminal volatile fatty acid concentrations were analyzed by gas chromatography using 2-ethyl butyric acid as an internal standard in a $25 \%$ (weight volume ${ }^{-1}$ ) meta-phosphoric acid solution (Goetsch and Galyean 1983).

During ruminal evacuations, MRDD were recovered, rinsed in cold water until all residue was removed, air-dried for 24 hours, and desiccated for 7 days. Weight of recovered MRDD was then subtracted from the initial weight, and the difference was assumed to be the loss of monensin and matrix from the bolus. The difference in MRDD weight was multipled by .3667 ( $16.5 \mathrm{~g}$ monensin in $45 \mathrm{~g}$ of core matrix) and divided by the number of days the MRDD was in the rumen to calculate daily monensin release rate. The design of MRDD is described in detail by Parrott et al. (1990).

Esophageal extrusa, ruminal digesta, and fecal samples were analyzed for 96-hour indigestible neutral detergent fiber (Krysl et al. 1988) and used to estimate indigestible neutral detergent fiber passage rates, ruminal turnover times, and apparent organic matter digestibility. Passage rates $\left(\%\right.$ hour $\left.^{-1}\right)$ of indigestible neutral detergent fiber were estimated as follows:

\section{(Daily INDF intake) (Ruminal INDF fill) \\ 24 hours}

Ruminal turnover time, or the average time that indigestible neutral detergent fiber spends in the rumen, was estimated as the reciprocal of the passage rate. Both passage rate and ruminal turnover estimates require an assumption of first-order ruminal kinetics. Apparent organic matter digestibility was calculated as:

$$
100-100\left[(\% \text { INDF in forage) (\% INDF in feces) })^{-1}\right]
$$

where INDF = indigestible neutral detergent fiber

Forage availability was estimated during each period by clipping randomly located, .2-m circular plots to a height of $2 \mathrm{~cm}$ on day 15 . Steins two-stage procedure was used to determine the number of plots necessary to estimate forage availability within $10 \%$ of the pasture mean (Pieper 1978).

Data were analyzed as a split-plot design, using the General Linear Models procedure of SAS (1988), with treatment (bolus) in the main plot and collection period in the subplot. Treatment effects were evaluated by an $F$ test when treatment $X$ period interactions were not significant $(P>.05)$. When significant interactions were detected, treatment effects were analyzed within period; differences among period means were separated by predicted difference (SAS 1988). Forage quality and bolus release data were analyzed as a randomized complete block (steers as blocks), with steer $\times$ period as the testing term.

\section{Results and Discussion}

Chemical analyses of esophageal masticate (Table 1) indicated a slight improvement in diet quality in October compared with August, and a decline in diet quality in November compared with

Table 1. Chemical composition and digestibility of diets selected by esophageally fistulated steers grazing blue grama rangeland.

\begin{tabular}{|c|c|c|c|c|}
\hline \multirow[b]{2}{*}{ Item $^{a}$} & \multicolumn{4}{|c|}{ Sampling period } \\
\hline & $\begin{array}{l}\text { Mid- } \\
\text { August }\end{array}$ & $\begin{array}{c}\text { Early } \\
\text { October }\end{array}$ & $\begin{array}{c}\text { Mid- } \\
\text { November }\end{array}$ & $S E^{\mathbf{b}}$ \\
\hline \multirow[t]{2}{*}{$\mathrm{OM}, \% \mathrm{DM}$} & 87.7 & 84.6 & 86.3 & .9 \\
\hline & $-{ }^{-1}$ & $---\%$ & OM $=--$ & -- \\
\hline NDF & $84.5^{\mathrm{d}}$ & $82.1^{e}$ & $89.5^{f}$ & .6 \\
\hline $\mathrm{ADF}$ & 50.2 & 52.9 & 55.9 & 1.5 \\
\hline ADL & 6.3 & 8.1 & 8.0 & .8 \\
\hline Nitrogen & $1.1^{\mathrm{d}}$ & $1.4^{\mathrm{e}}$ & $.9^{\mathrm{d}}$ & .05 \\
\hline ADIN & .2 & .2 & .2 & .02 \\
\hline Available $\mathbf{N}^{\mathrm{c}}$ & $.9^{d}$ & $1.2^{\mathrm{e}}$ & $.7^{d}$ & .07 \\
\hline INDF & $23.1^{\mathrm{d}}$ & $26.9^{\text {de }}$ & $30.4^{\mathrm{e}}$ & .8 \\
\hline IVOMD & $53.7^{\mathrm{d}}$ & $53.7^{d}$ & $48.7^{\circ}$ & .9 \\
\hline
\end{tabular}

${ }^{a} \mathrm{OM}=$ organic matter; $\mathrm{NDF}=$ neutral detergent fiber; $\mathrm{ADF}=$ acid detergent fiber; ADL = acid detergent lignin; ADIN = acid detergent insoluble $\mathrm{N} ; \mathrm{INDF}=$ indigestible ADL = acid detergent lignin; ADIN = acid detergent insol
NDF; IVOMD = in vitro organic matter disappearance.

Standard error of least squares means, $n=3$ (mid-November $n=2)$

Available $\mathbf{N}=$ Total kjeldahl $\mathbf{N}-$ ADIN.

Means in the same row with different superscripts differ $(P<.05)$ 


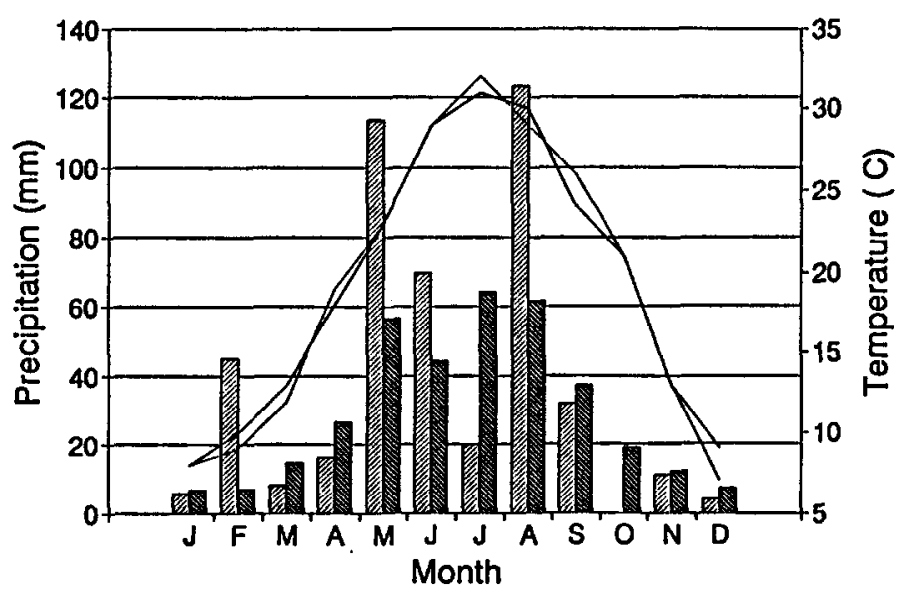

PPT 1987 PPT 1951-80 Temp 1987 Temp 1951-80

Fig. 1. Average monthly maximum temperature (Temp) and precipitation (PPT) for Clayton, N.M., for 1987 (New Mexico State Climatologist 1988), and for years 1951 to 1980 (NOAA 1985).

both August and October. Differences $(P<.05)$ in masticate neutral detergent fiber content were noted among all periods. In addition, esophageal masticate contained less $(P<.05)$ available $\mathrm{N}$ in November and August than in October. Masticate in vitro organic matter disappearance did not differ $(P>.05)$ in August and October $(53.7 \%)$ but was least $(P<.05)$ in November $(48.7 \%)$. Precipitation in July was $30 \%$ of normal (Fig. 1), and most of the August precipitation fell after the August collection period, suggesting that the August period reflects summer drought conditions. High precipitation in late August and nearly normal precipitation in September, as well as increased growth of cool-season grasses (Table 2), indicate that extrusa samples collected in October correspond to a period of late-season growth. Low temperatures in November and low precipitation in October and November indicate a period of early winter dormancy for forage in November.

Forage availablity data (Table 2) were collected to determine if availability might limit forage intake. Forage availability increased from $987 \mathrm{~kg} \mathrm{ha}^{-1}$ in August to $1,093 \mathrm{~kg} \mathrm{ha}^{-1}$ in October, then declined to $790 \mathrm{~kg} \mathrm{ha}^{-1}$ in November. Data concerning forage conditions, including forage availability, that are likely to affect forage intake are limited for this range type. A decline in forage intake attributed to fatigue appears to occur when grazing time exceeds approximately 10.8 hours on crested wheatgrass pastures (Agropyron cristatum L. and Agropyron desertorum Fisch.; Scarnecchia et al. 1985) and 12 hours on tropical pastures (Stobbs 1975). Although total grazing time was not quantified, observations during the daylight hours indicate grazing times were less than 10 hours per day for all periods of our study. Further, studies by Handl and Rittenhouse (1972) on crested wheatgrass pastures indicate that dry matter intake by steers was not limited at or above forage availability of $176 \mathrm{~kg} \mathrm{ha}^{-1}$.

Estimated bolus release rate in our study was $68 \mathrm{mg} \mathrm{day}^{-1}(\mathrm{SD}=$ 8.8). Release was $32 \%$ less than the manufacturer specified release rate $\left(100 \mathrm{mg} \mathrm{day}^{-1}\right)$, but similar to release rates described by Conrad and Skinner (1989). Release rate did not vary $(P>.10)$ by period, but a steer (bolus) effect was observed $(P=.054)$. Other researchers using MRDD found the release rate to be at, or near $100 \mathrm{mg} \mathrm{day}^{-1}$ (Davenport et al. 1989, Ward et al. 1990a, 1990b). According to Conrad and Skinner (1989) release of monensin depends on hydration and abrasion of the core material. Initially the core faces are less hydrated, and firmer, lessening the effect of abrasion by ruminal contents on release of monensin from the core material. This initial lag phase, resulting from hydration, suggests that ruminal delivery of monensin during the collection period may have been greater than observed for the entire 35 days. Knowledge of this lag phase may affect the interpretation of results reported by others (Davenport et al. 1989; Ward et al. 1990a, 1990b). Differences in release rate also may result from different procedural methodology (cleaning and drying of boluses), differences among batches or, more likely, forage type.

Forage intake ( $15.4 \mathrm{vs} 14.4 \mathrm{~g}$ organic matter $\mathrm{kg}^{-1}$ body weight for control and MRDD, respectively) and apparent organic matter digestion ( 56.5 vs 57.7 for control and MRDD, respectively) were not affected $(P>.10)$ by bolus; however, differences among periods were detected (Table 3). Organic matter digestibility, as estimated by the indigestible neutral detergent fiber ratio technique, was greater $(P<.05)$ during August than during either October or November, which did not differ $(P>.10)$. Forage intake varied

Table 2. Species composition a and forage availability of study pasture for 3 periods.

\begin{tabular}{|c|c|c|c|}
\hline \multirow[b]{2}{*}{ Species } & \multicolumn{3}{|c|}{ Sampling period } \\
\hline & Mid-August & Early October & Mid-October \\
\hline Grasses: & \multicolumn{3}{|c|}{ 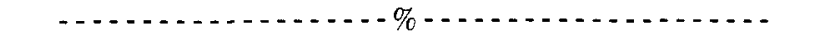 } \\
\hline Blue grama (Bouteloua gracilis H.B.K.) & 64.4 & 56.3 & 73.7 \\
\hline Buffalograss ( Buchole dactyloides Nutt.) & 3.9 & 2.1 & 5.2 \\
\hline Sideoats grama (Bouteloua curtependula Michx.) & 4.9 & 3.7 & 2.8 \\
\hline Tobosa grass (Hilaria mutica Buckl.) & 11.7 & 9.2 & 6.7 \\
\hline Bottlebrush squirreltail (Sitanion hystrix Nutt.) & 4.5 & 5.8 & 3.1 \\
\hline Western wheatgrass (Agropyron smithii Rydb.) & & 4 & .6 \\
\hline Sand dropseed (Sporobulus cryptandrus Torr.) & .4 & 1.4 & 1.2 \\
\hline Silver bluestem (Andropogon saccharoides Steud.) & & .5 & \\
\hline Vine mesquite (Panicum obtusum H.B.K.) & & 2.1 & 1.6 \\
\hline Threeawns (Aristida sp.) & 3.8 & 5.6 & 4.3 \\
\hline Japanese brome (Bromus japonicus Thunb.) & Trace & 3 & .2 \\
\hline \multicolumn{4}{|l|}{ Forbs: } \\
\hline Slim flower scurf-pea (Psoralea tenuiflora Pursh) & 3.5 & 4 & Trace \\
\hline Scarlet globe-mallow ( Spaeralcea coccinea Pursh) & 1 & .3 & \\
\hline Milk-vetch ( Astragulus sp.) & & Trace & \\
\hline Other & .5 & 1.2 & \\
\hline Forage availability, $\mathrm{kg} \mathrm{ha}^{-1}$ & 987 & 1,093 & 790 \\
\hline
\end{tabular}

${ }^{\mathrm{a} N o m e n c l a t u r e ~ f o l l o w s ~ G r e a t ~ P l a i n s ~ F l o r a ~ A s s o c i a t i o n, ~} 1986$. 
Table 3. Body weight (BW), forage organic matter $(\mathrm{OM})$ intake, ruminal fill and indigestible neutral detergent fiber (INDF) passage rate and retention time of steers grazing blue grama rangeland during periods of differing forage maturity.

\begin{tabular}{|c|c|c|c|c|}
\hline \multirow[b]{2}{*}{ Item } & \multicolumn{4}{|c|}{ Sampling period } \\
\hline & $\begin{array}{l}\text { Mid- } \\
\text { August }\end{array}$ & $\begin{array}{c}\text { Early } \\
\text { October }\end{array}$ & $\begin{array}{c}\text { Mid- } \\
\text { November }\end{array}$ & $\mathrm{SEM}^{8}$ \\
\hline Steer $\mathbf{B W}, \mathbf{k g}$ & $336^{\mathrm{e}}$ & $360^{f}$ & $347^{8}$ & 3.0 \\
\hline Fecal output, $\mathrm{g} O M \mathrm{~kg}^{-1} \mathrm{BW}$ & N 6.8 & 7.6 & 7.0 & .5 \\
\hline $\mathrm{OMD}^{\mathrm{b}}, \%$ & $62.3^{e}$ & $55.2^{f}$ & $53.9^{f}$ & .7 \\
\hline \multicolumn{5}{|l|}{ Forage intake: } \\
\hline 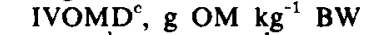 & $14.6^{\mathrm{hi}}$ & $16.4^{\mathrm{h}}$ & $13.6^{i}$ & .9 \\
\hline $\mathrm{OMD}^{\mathrm{d}}, \mathrm{g} \mathrm{OM} \mathrm{kg} \mathrm{MW}^{-1} \mathrm{BW}$ & $18.0^{\mathrm{h}}$ & $17.4^{\mathrm{hi}}$ & $15.1^{\mathrm{i}}$ & 1.1 \\
\hline Ruminal fill, $\mathrm{g} \mathrm{kg}^{-\mathrm{r}} \mathrm{BW}$ & $161.8^{e}$ & $166.9^{f}$ & $163.7^{e}$ & 2.3 \\
\hline Ruminal DM fill, $\mathrm{g} \mathrm{kg}^{-1} \mathrm{BW}$ & $\mathrm{V} 22.9^{\mathrm{e}}$ & $30.6^{\mathrm{f}}$ & $28.9^{\mathrm{f}}$ & .9 \\
\hline Ruminal $\mathrm{OM}$ fill, $\mathrm{g} \mathrm{kg}^{-1} \mathrm{BW}$ & V $19.5^{e}$ & $24.7^{\mathrm{f}}$ & $23.5^{f}$ & .8 \\
\hline Ruminal NDF fill, $\mathrm{g} \mathrm{kg}^{-1} \mathrm{BW}$ & $N 15.4^{\mathrm{e}}$ & $21.4^{\mathrm{f}}$ & $20.7^{f}$ & 6 \\
\hline Ruminal INDF fill, $\mathrm{g} \mathrm{kg}^{-1} \mathrm{BW}$ & $7.7^{e}$ & $10.5^{f}$ & $12.7^{\mathrm{g}}$ & .3 \\
\hline INDF passage rate, $\%$ hour ${ }^{-1}$ & $-1 \quad 1.9^{\mathrm{e}}$ & $1.8^{\mathrm{e}}$ & $1.5^{\mathrm{f}}$ & .1 \\
\hline INDF retention time, hours & $57^{\mathrm{e}}$ & $57^{e}$ & $80^{f}$ & 6.9 \\
\hline
\end{tabular}

Standard error of least-squares means.

$\mathrm{OMD}=$ apparent organic matter digestibility, calculated from INDF concentrations of forage and fecal samples.

${ }^{\circ}$ Calculated using in vitro organic matter disappearance (IVOMD) estimates of esophageal extrusa.

phageal extrusa. INDF.

e,f. Row means within period with different superscripts differ $(P<.05)$.

h,i $R$ ow means within period with different superscripts differ $(P<.10)$,

$(P<.10)$ with collection period and method of calculating indigestibility. Intake based on in vitro organic matter disappearance was greater $(P<.10)$ in October than in November $(16.4$ and $13.6 \mathrm{~g}$ organic matter $\mathrm{kg}^{-1}$ body weight for October and November, respectively), with August ( $14.6 \mathrm{~g}$ organic matter $\mathrm{kg}^{-1}$ body weight) not different than either October or November $(P>.10)$. This would be expected given greater concentrations of available $\mathrm{N}$ as well as lower neutral detergent fiber concentrations in esophageal extrusa during October, which should affect forage intake positively (Van Soest 1982). Forage intake estimates based on indigestible neutral detergent fiber as a measure of indigestibility were greater than estimates using in vitro organic matter disappearance for all periods. In August, forage intake was greater $(P<.10)$ than in November (18 and $15.1 \mathrm{~g}$ organic matter $\mathrm{kg}^{-1}$ body weight for August and November, respectively) with October (17.4 g organic matter $\mathrm{kg}^{-1}$ body weight) not different ( $\left.P>.10\right)$ from either August or November. It is uncertain which estimates are more accurate; yet, estimates based on indigestible neutral detergent fiber are similar to those of reported by Funk et al. (1987) for the same pasture in 1985 with similar pasture conditions. In addition, apparent organic matter digestibility estimates using indigestible neutral detergent fiber were greater in August when ruminal ammonia concentrations did not appear to potentially limit microbial protein synthesis.

Research conducted by Lippke (1986) led him to conclude that indigestible neutral detergent fiber becomes the intake-limiting constituent of forages when indigestible neutral detergent fiber exceeds $15 \%$ of the forage organic matter. In our study, indigestible neutral detergent fiber (Table 1) as a proportion of forage organic matter was least in August (23.1\%) and increased $(P<.05)$ each period from August to November ( $30.4 \%$ ). If forage indigestible neutral detergent fiber is a good indicator of forage intake, then it would be expected that forage intake should decline as forage indigestible neutral detergent fiber increases. Furthermore, Lippke's data suggest a linear relationship between forage indigestible neutral detergent fiber and forage intake. However, our forage organic matter intake estimates using in vitro organic matter disappearance did not conform to the expected pattern. Indeed, efforts to predict forage intake (based on in vitro organic matter disappearance estimates) as a function of forage indigestible neutral detergent fiber alone would have produced erroneous results.

Ellis et al. (1984) reported that monensin supplementation of steers with grain as a carrier $\left(.45\right.$ or $\left..91 \mathrm{~kg} \mathrm{day}^{-1}\right)$ increased intake of forages ranging from 45 to $65 \%$ apparent organic matter digestibility and decreased intake when apparent organic matter digestibility exceeded $65 \%$. Conversely, when supplemented via MRDD, monensin had no effect on forage intake by steers grazing native tall grass pastures with an organic matter digestibility of approximately $70 \%$ (Cochran et al. 1990), winter wheat pastures (in vitro dry matter disappearance ranging from 59 to $71 \%$; Davenport et al. 1989 ) or northern mixed prairie summer (apparent organic matter digestibility of approximately $60 \%$; Ward et al. 1990a), and winter pasture (apparent organic matter digestibility of approximately $60 \%$; Ward et al. 1990b). Results of our study agree with previous experiments using MRDD.

In 13 grazing trials reported by Ellis et al. (1984), monensin increased apparent organic matter digestibility by $4 \%$, with the greatest effect on less digestible forages. In a study reported by Ward et al. (1990a) MRDD increased apparent organic matter digestibility from 60.4 to $62.2 \%$ by steers grazing native range without, and with MRDD, respectively; however, apparent organic matter digestibility was not affected by MRDD in other studies (Cochran et al. 1990, Ward et al. 1990b). In the study reported by Ward et al. (1990b), unsupplemented steers grazing native winter range had a mean apparent organic matter digestibility of $57.6 \%$, whereas Cochran et al. (1990) reported a mean apparent organic matter digestibility of $68.7 \%$ for unsupplemented heifers grazing early-summer bluestem range.

Ruminal fill estimates did not differ $(P>.10)$ between treatments. Ruminal organic matter fill was 22.7 and $22.4 \mathrm{~g}$ organic matter $\mathrm{kg}^{-1}$ body weight for control and MRDD, respectively. Ruminal neutral detergent fiber fill was $19.2 \mathrm{~g}$ neutral detergent fiber $\mathrm{kg}^{-1}$ body weight for both control and MRDD. Ellis et al. (1984) suggested that an increase in ruminal undigested dry matter fill might explain the observed increase in forage intake caused by monensin. The absence of an effect of monensin on ruminal fill in our study, as well as those of Cochran et al. (1990) and Ward et al. (1990b), may be associated with the lack of differences in forage intake because ruminal fill appears to be one factor limiting intake (Freer 1981).

Ruminal organic matter fill did not differ $(P>.05)$ in October and November ( 24.7 and $23.5 \mathrm{~g} \mathrm{~kg}^{-1}$ body weight for October and November, respectively), but ruminal organic matter fill was less $(P<.05)$ in August $\left(19.5 \mathrm{~g} \mathrm{~kg}^{-1}\right.$ body weight) than in later periods. This pattern also was observed for ruminal neutral detergent fiber fill (Table 3). Ruminal fill increases with increased forage intake (Balch and Campling 1965) or advancing forage maturity (McCollum and Galyean 1985). Forage intake did not increase with ruminal fill; therefore, it is likely that increasing forage maturity, as indicated by apparent organic matter digestibility, influenced ruminal fill.

Because neither forage intake nor ruminal fill were affected by MRDD, MRDD would not be expected to affect ruminal passage rate or retention time estimates; this was in fact the case $(P>.10)$. Indigestible neutral detergent fiber passage rates were 1.8 and $1.6 \%$ hour $^{-1}$ for control and MRDD, respectively. Indigestible neutral detergent fiber retention time was 59 and 70 hours for control and MRDD, respectively. When monensin was fed with grain as a carrier, passage rates were decreased; therefore, retention time should increase (Ellis et al. 1984). Results of our study and those of Ward et al. (1990a, 1990b) do not support this finding when monensin was supplemented via MRDD. Differences in passage rates and retention times were detected $(P<.05)$ among periods 
(Table 3). Indigestible neutral detergent fiber passage rates in August and October did not differ $\left(P<.10 ; 1.9\right.$ and 1.8 hour $^{-1}$ for August and October, respectively), but were less $(P>.05)$ in November ( $1.5 \%$ hour $\left.^{-1}\right)$ than for either August or October. Likewise, indigestible neutral detergent fiber retention time was 57 hours in August and October and increased $(P<.05)$ to 80 hours in November. Our steers appeared to compensate for the lower forage quality in November by increasing ruminal fill and ruminal particulate retention time and decreasing ruminal passage rates. A similar response was observed by McCollum and Galyean (1985).

Ruminal ammonia concentrations were not affected $(P>.10)$ by

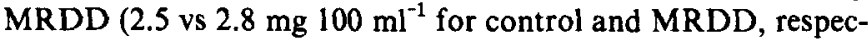
tively). Monensin sometimes decreases ruminal ammonia concentrations (Poos et al. 1979, Branine 1987), suggesting decreased microbial proteolysis; however, Dinius et al. (1976) found that monensin did not decrease ruminal ammonia concentrations in steers fed forage diets. Likewise, MRDD did not affect ruminal ammonia concentrations in other studies (Davenport et al. 1989; Cochran et al. 1990; Ward et al. 1990a, 1990b).

Ruminal ammonia concentrations (data not shown) varied $(P<.05)$ among periods. Ammonia concentrations in October $(.01)$ and November $\left(.47 \mathrm{mg} 100 \mathrm{ml}^{-1}\right)$ were less than values recommended by Stanton et al. (1983) and $Q$ rskov (1982) for maximal microbial protein synthesis, whereas the August $\left(7.4 \mathrm{mg} 100 \mathrm{ml}^{-1}\right)$ values exceeded these recommendations. Lower ruminal ammonia and decreased apparent digestibility of the diet in October and November may explain the increased ruminal fill in these 2 periods. Ruminal ammonia concentrations in October and November were less than values typically reported for blue grama rangeland, and may be the result of sampling from ruminal digesta once it had been removed from the rumen; previous studies obtained fluid directly from the rumen.

Ruminal pH (data not shown) was not affected $(P>.10)$ by MRDD (6.5 and 6.4 for control and MRDD, respectively) or by grazing season (6.4 and 6.5 for August and November, respectively; data for October was not obtained because of electrode failure). These results agree with studies in which monensin was fed (Poos et al. 1979), and those using MRDD (Davenport et al. 1989; Cochran et al. 1990; Ward et al. 1990a, 1990b). Although pH measurements were below optimal values (6.7) for ruminal forage digestion proposed by Mertens (1977), they were well above the minimal limits (6.2) suggested by $Q$ rskov (1982).

A treatment $\times$ period interaction $(P=.046)$ was detected for in situ neutral detergent fiber disappearance at 9 hours of incubation. Monensin ruminal delivery devices decreased $(P<.10)$ in situ neutral detergent fiber disappearance at 9 hours in October (15.6 and $11.2 \%$ for control and MRDD, respectively), and increased $(P<.05)$ neutral detergent fiber disappearance at 9 hours in November (20.4 and $22.7 \%$ for control and MRDD, respectively). Across periods, in situ neutral detergent fiber disappearance was decreased $(P>.10)$ by MRDD at 96 hours (68 vs $65 \%$ for control and MRDD, respectively). Differences $(P>.10)$ in rate of disappearance were not observed for either MRDD (2.4 vs $2.7 \%$ hour $^{-1}$ for control and MRDD, respectively) or period (3.2, 2.4, and $2.11 \%$ hour $^{-1}$ for August, October, and November, respectively). Across treatments, disappearance of neutral detergent fiber from nylon bags at 3,6 , and 12 hours was greater $(P<.05)$ in November, whereas disappearance was least $(P>.05)$ in November and greatest in August at 48 hours (Figure 2).

Ruminal acetate proportions were greater $(P<.05)$ in October (73.9) and November (74.0) than in August (71.3 mol $\left.100 \mathrm{~mol}^{-1}\right)$. Propionate proportions also were greater $(P<.05)$ in October (17.7) and November (17.9) than in August (16.4 mol $\left.100 \mathrm{~mol}^{-1}\right)$. During periods when both acetate and propionate were greater, butyrate proportions were less $(P<.05 ; 10.0,7.3$, and $7.5 \mathrm{~mol} 100$

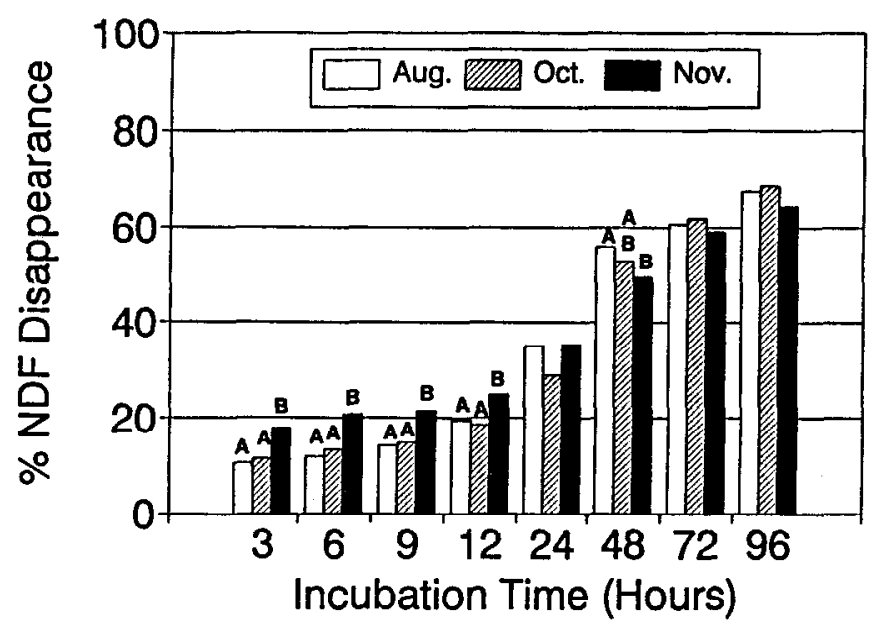

Fig. 2. Percentage in situ neutral detergent fiber (NDF) disappearance of esophageal masticate during mid August (Aug.), early October (Oct.), and mid November (Nov.) using steers grazing native blue grama rangeland. A treatment by period interaction $(P<.05)$ occurred for 9 hours. Means within hour with different superscripts differ $(P<.05)$.

$\mathrm{mol}^{-1}$ for August, October, and November, respectively). Volatile fatty acid concentrations and production vary with chemical composition of feedstuffs (Murphy et al. 1982). During ruminal fermentation of forages, acetate-to-propionate ratios generally increase with increasing forage maturity (Van Soest 1982).

Monensin ruminal delivery devices had only small effects on minor volatile fatty acids. Concentrations of isobutyrate (.5 and .4 mol $100 \mathrm{~mol}^{-1}$ for control and MRDD, respectively) and valerate (.6 and $.4 \mathrm{~mol} / 100 \mathrm{~mol}^{-1}$ for control and MRDD, respectively) were decreased $(P<.05)$ with MRDD; however, other volatile fatty acids were unaffected $(P>.10)$. The observed effect of MRDD on minor volatile fatty acids were extremely small and probably not significant biologically. The ability of monensin to alter volatile fatty acid proportions by increasing propionate production at the expense of acetate has been well documented (Galyean and Owens 1988, Russell and Strobel 1989), but when monensin has been provided via MRDD, results have been variable. Davenport et al. (1989) reported a slight increase in propionate, but no effect on acetate proportions, as a result of MRDD treatment. Ward et al. (1990a) also detected a slight increase in proportions of propionate, and decreased acetate and butyrate in steers bolused with MRDD while grazing native summer range. Nonetheless, MRDD did not affect volatile fatty acid concentrations of steers grazing native winter range (Ward et al. 1990b). Further, Cochran et al. (1990) reported that MRDD slightly increased acetate proportions.

\section{Conclusions}

Monensin administered via a MRDD had only minor effects on in situ neutral detergent fiber disappearance and volatile fatty acid proportions. As mentioned previously, MRDD did not elicit the same responses as reported in studies where monensin was supplemented with a grain carrier. Davenport et al. (1989) stated that ruminal monensin concentration patterns within day may vary between fed and ruminally dispensed techniques. When a pulse dose of monensin is administered, the ruminal monensin concentration is high at dosing and declines over time. In contrast, monensin dispensed via MRDD should achieve equilibrium at a lower concentration and remain more constant over time. Although not examined in our study, such differences in ruminal concentration patterns may have altered the effectiveness of monensin.

Although not evident in our study, forage characteristics may largely determine the efficacy of MRDD. Daily gains were 
recorded in a series of studies designed to test the efficacy of MRDD (Parrott et al. 1990). In this report, steers receiving MRDD while grazing predominantly native range had $2.3 \%$ greater daily gain than steers not receiving MRDD. However, Cochran et al. (1990) reported that average daily gains by steers grazing native bluestem range were not affected by MRDD, whereas Davenport et al. (1989) found MRDD increased average daily gain by $13.6 \%$ for steers grazing wheat pasture. Of the ruminal fermentation characteristics measured, only VFA proportions were affected in the study conducted by Davenport et al. (1989). Collectively, these results support the existence of a forage quality $X$ monensin interaction. This little-understood interaction may, at least in part, explain the lack of influence of MRDD on forage digestion in our study. The MRDD that we used possibly had a lower daily release rate than observed in other studies, which also may have contributed to the lack of response.

As the grazing season progressed, a general decrease in forage intake accompanied by increased ruminal fill and retention time and decreased particulate passage rate was noted. These factors may offset declining forage quality by increasing the residence time of forages and therefore the potential digestibility of the forage. Initially, in situ neutral detergent fiber disappearance was greater with the more mature forages; yet, this difference declined as incubation time increased, whereas neutral detergent fiber disappearance was least for less mature forages after 48 hours of incubation. Acetate and propionate concentrations also increased with advancing forage maturity at the expense of butyrate and minor volatile fatty acids.

\section{Literature Cited}

AOAC. 1984. Official methods of analysis (14th Ed.). Assoc. Official Analyt. Chem. Washington, D.C.

Balch, C.C., and R.C. Campling. 1965. Rate of passage through the ruminant digestive tract. p. 108-123. In: R.W. Dougherty (ed.), Physiology of digestion of the ruminant. Butterworths, Washington, D.C.

Branine, M.E., and M.L. Galyean. 1990. Influence of grain and monensin supplementation on ruminal fermentation, intake, digesta kinetics and incidence and severity of frothy bloat in steers grazing winter wheat pasture. J. Anim. Sci. 68:1139-1150.

Broderick, G.A., and J.H. Kang. 1980. Automated simultaneous determinations of ammonia and total amino acids in ruminal fluid and in vitro media. J. Dairy Sci. 63:64-75.

Cochran, R.C., E.S. Vanzant, J.G. Riley, and C.E. Owensby. 1990. Influence of intraruminal monensin administration on performance and forage use in beef cattle grazing early-summer bluestem range. J. Prod. Agr. 3:88-92.

Conrad, J.M., and D.S. Skinner. 1989. Controlled sustained delivery of monensin in cattle: the monensin R.D.D.J. Controlled Release 9:133-147.

Davenport, R.W., M.L. Galyean, M.E. Branine, and M.E. Hubbert. 1989. Effects of a monensin ruminal delivery device on daily gain, forage intake and ruminal fermentation of steers grazing irrigated winter wheat pasture. J. Anim. Sci. 67:2129-2139.

Dinius, D.A., M.E. Simpson, and P.B. Marsh. 1976. Effect of monensin fed with forage on digestion and the ruminal ecosystem of steers, J. Anim. Sci. 42:229-234.

Dinius, D.A., H.K. Goering, R.R. Oltjen, and H.R. Cross. 1978. Finishing beef steers on forage diets with additives and supplemental lipid. J. Anim. Sci. 46:761-768.

Ellis, W.C., G.W. Horn, D. Delaney, and K.R. Pond. 1984. Effects of ionophores on grazed forage utilization and their economic value for cattle on wheat pastures. p. 343-355. In: G.W. Horn (ed.) Proc. Nat. Wheat Pasture Symp. Oklahoma Agr. Exp. Sta., MP 115.

Freer, M. 1981. The control of food intake in grazing animals. p. 105-124. In: F.H.W. Morley (ed.) Grazing animals. Elsevier Scientific Publ. Co., N.Y.

Funk, M.A., M.L. Galyean, M.E. Branine, and L.J. Krysl. 1987. Steers grazing blue grama rangeland throughout the growing season. I. Dietary composition, intake, digesta kinetics and ruminal fermentation. J. Anim. Sci. 65:1342-1353.

Galyean, M.L., and F.N. Owens. 1988. Effects of monensin on growth, reproduction, and lactation in ruminants. p. 71-74. ISI Atlas of Science, Plant and Anim. Sci.
Goering, H.K., and P.J. Van Soest. 1970. Forage fiber analyses (apparatus, reagents, procedures, and some applications). Agr. Handb. 379, ARS, USDA, Washington, D.C.

Goetsch, A.L., and M.L. Galyean. 1983. Influence of feeding frequency on passage of fluid and particulate markers in steers fed a concentrate diet. Can. J. Anim. Sci. 63:727-730.

Goodrich, R.D., J.E. Garrett, D.R. Gast, M.A. Kirick, D.A. Lanson, and J.C. Meiske. 1984. Influence of monensin on the performance of cattle. J. Anim. Sci. 58:1484-1498.

Great Plains Flora Association. 1986. Flora of the Great Plains. T.M. Barkley Ed. Univ. Press of Kansas, Lawrence.

Handl, W.P., and L.R. Rittenhouse. 1972. Herbage yield and intake of steers. Proc. West. Sec. Amer. Soc. Anim. Sci. 23:197-200.

Horn, G.W., T.L. Mader, S.L. Armbruster, and R.R. Frahm. 1981. Effect of monensin on ruminal fermentation, forage intake and weight gains of wheat pasture stocker cattle. J. Anim. Sci. 52:447-454.

Krysl, L.J., M.L. Galyean, R.E. Estell, and B.F. Sowell. 1988. Estimating digestibility and faecal output in lambs using internal and external markers. J. Agr. Sci. (Camb.) 11:19-25.

Lippke, H. 1986. Regulation of voluntary intake of ryegrass and sorghum forages in cattle by indigestible neutral detergent fiber. J. Anim. Sci. 63:1459-1468.

McCollum, F.T., and M.L. Galyean. 1985. Cattle grazing blue grama rangeland II. Seasonal forage intake and digesta kinetics. J. Range Manage. 38:543-546.

Mertens, D.R. 1977. Dietary fiber components: relationship to the rate and extent of ruminal digestion. Fed. Proc. 36:187-192.

Mertens, D.R., and J.R. Loften. 1980. The effect of starch on fiber digestion kinetics in vitro. J. Dairy Sci. 63:1437-1446.

Muller, R.D., E.L. Potter, M.I. Wray, L.F. Richardson, and H.P. Grueter. 1986. Administration of monensin in self fed (salt limiting) dry supplements or on a alternate-day feeding schedule. J. Anim. Sci. 62:593-600

Murphy, M.R., R.L. Baldwin, and L.J. Koong. 1982. Estimation of stoichiometric paramaters for rumen fermentation of roughage and concentrate diets. J. Anim. Sci. 55:411-421.

New Mexico State Climatologist. 1988. Remote weather station data summary. New Mexico Dep. Agr., Las Cruces.

NOAA. 1985. Climates of the States (3rd ed.). Nat. Oceanic and Atmospheric Admin. Gale Research Company, Detroit, Mich.

Oliver, W.M. 1975. Effect of monensin on gains of steers grazed on coastal Bermuda grass. J. Anim. Sci. 41:999-1001.

Orskov, E.R., and I. McDonald. 1970. The estimation of protein degradability in the rumen from incubation measurements weighted according to rate of passage. J. Agr. Sci. (Camb.) 92:499-503.

Orskov, E.R. 1982. Protein nutrition in ruminants. Academic Press Inc., N.Y.

Parrott, J.C., R.P. Basson, J.M. Conrad, N.G. Elliston, H.P. Grueter, F.E. Livesay, J.W. McAskill, R.M. Meyer, R.D. Olson, and L.D. Pendlum. 1986. Effect of monensin ruminally delivery devices on rate of weight gain of pasture cattle. J. Anim. Sci. 63(Suppl. 1):304 (Abstr.).

Parrott, J.C., J.M. Conrad, R.P. Basson, and L.C. Pendlum. 1990. The effect of a monensin ruminal delivery device on performance of cattle grazing pasture. J. Anim. Sci. 68:2614-2621.

Pieper, R.D. 1978. Measurement techniques for herbaceous and shrubby vegetation. New Mexico State Univ., Las Cruces.

Poos, M.I., T.L. Hanson, and T.J. Klopfenstein. 1979. Monensin effects on diet digestibility, ruminal protein bypass and microbial protein synthesis. J. Anim. Sci. 48:1516-1523.

Pooter, E.L., C.O. Cooley, L.F. Richardson, A.P. Rahn, and L.P. Rathmacher. 1976. Effect of monensin on performance of cattle fed forage. $J$. Anim. Sci. 43:665-669.

Russell, J.B., and H.J. Strobel. 1989. Effect of ionophores on ruminal fermentation. Appl. Environ. Microbiol. 55:1-6.

SAS. 1988. SAS user's guide: Statstics. Version 5. SAS Inst. Inc., Cary, N.C.

Scarncecchia, D.L., A.S. Nastis, and J.C. Malechek. 1985. Effects of forage availability on grazing behavior of heifers. J. Range Manage. 38:177-180.

Sprott, L.R., T.B. Goehring, J.R. Beverly, and L.R. Corah. 1988. Effects of ionophores on cow herd production: a review. J. Anim. Sci. 66:1340-1346.

Stanton, T.L., F.N. Owens, and K.S. Lusby. 1983. Formaldehyde-treated soybean meal for ruminants grazing winter range grass. J. Anim. Sci. $56: 6-14$

Stobbs, T.H. 1975. Factors limiting the nutritional value of grazed tropical pastures for beef and milk production. Trop. Grassl. 9:141-150. 
Thornton, J.H., and F.N. Owens. 1981. Monensin supplementation and in vivo methane production by steers. J. Anim. Sci. 52:628-634.

Tilley, J.M.A., and R.A. Terry. 1963. A two stage procedure of the in vitro digestion of forage crops. J. Brit. Grassl. Soc. 18:104-111.

Van Soest, P.J. 1982. Nutritional ecology of the ruminant. $O$ and B Books, Corvallis, Ore.

Wagner, J.F., H. Brown, N.w. Bradley, w. Dinusson, w. Dunn, N. Elliston, J. Miyat, D. Mowrey, J. Moreman, L.C. Pendlum, C. Parrott L. Richardson, I. Rush, and H. Woody. 1984. Effect of monensin, estradiol controlled release implants and supplement on performance in grazing steers. J. Anim. Sci. 58:1062-1067.
Ward, M.G., D.C. Adams, J.D. Wallace, M.L. Galyean, and B.W. Knapp. 1990a. Supplementation and monensin effects on digesta kinetics. I. Cattle grazing summer range. J. Range Manage. 43:378-382.

Ward, M.G., D.C. Adams, J.D. Wallace, M.L. Galyean, and J.D. Volesky. 1990b. Supplementation and monensin effects on digesta kinetics. II. Cattle grazing winter range. J. Range Manage. 43:383-386.

Wedegaertner, T.C., and D.E. Johnson. 1983. Monensin effects on digestibility, methanogenesis and heat increment of a cracked corn-silage diet fed to steers. J. Anim. Sci. 57:168-177. 